\title{
ПРОБЛЕМИ ПРИВЕДЕННЯ КРИМІНАЛЬНОГО ЗАКОНОДАВСТВА УКРАЇНИ У ВІДПОВІДНІСТЬ ІЗ ВИМОГАМИ СТАМБУЛЬСЬКОЇ ТА ЛАНСАРОТСЬКОÏ КОНВЕНЦІЙ
}

\begin{abstract}
Статтю присвячено прийнятим у 2017-2018 роках законодавчим новелам у сфері кримінальної відповідальності за злочини проти статевої свободи та статевої недоторканості особи. Одними з пріоритетних цілей цих новел було приведення українського кримінального закону у відповідність із вимогами Конвенції Ради Європи про запобігання насильству стосовно жінок і домашньому насильству та боротьбу з цими явищами від 2011 року (Стамбульська конвенція) та Конвенції Ради Європи про захист дітей від сексуальної експлуатації та сексуального насильства від 2007 року (Лансаротська конвенція). У статті констатується, що вказані цілі не були досягнути повністю, та аналізуються неузгодженості між новими положеннями кримінального законодавства та положеннями Стамбульської та Лансаротської конвенцій.
\end{abstract}

Ключові слова: злочини проти статевої свободи і недоторканності, сексуальне насильство, домашнє насильство, гармонізація кримінального законодавства.

Статья посвящена принятым в 2017-2018 годах законодательным новеллам в сфере уголовной ответственности за преступления против половой свободы и половой неприкосновенности личности. Одними из приоритетных целей этих новелл было приведение украинского уголовного закона в соответствие с требованиями Конвенции Совета Европы о предотвращении насилия в отношении женщин и домашнего насилия и борьбу с этими явлениями от 2011 года (Стамбульская конвенция) и Конвенции Совета Европы о защите детей от сексуальной эксплуатации и сексуального насилия от 2007 года (Лансаротская конвенция). B cmamье констатируется, что указанные цели не были достигнуты полностью, и анализируются рассогласования между новыми положениями уголовного законодательства и положениями Стамбульской и Лансаротськои конвенций.

Ключевые слова: преступления против половой свободы и неприкосновенности, сексуальное насилие, домашнее насилие, гармонизация уголовного законодательства.

The article is dedicated to the legislative novelties in the field of criminal responsibility for crimes against sexual freedom and sexual integrity adopted in 2017-2018. Ones of the priority goals of these novelties was to align Ukrainian criminal law with the requirements of the 2011 Council of Europe Convention on the Prevention of Violence against Women and Domestic Violence (Istanbul Convention) and the 2007 Council of Europe Convention on the Protection of Children against Sexual Exploitation and Sexual Violence (Lanzarote Convention). Unfortunately, this goal was only partially achieved and the criminal law is largely inconsistent with the provisions of the aforementioned conventions.

The introduction of the concept of "age below which engaging in sexually explicit activities with a child is prohibited" into criminal law has taken place in a very inconsistent and haphazard manner. The wording "natural or unnatural sexual intercourse" in the current edition of Part 1 of Art. 155 of the Criminal Code does not cover all situations denoted by the conventional con-

\section{Давидович І. І., Задоя К. П.}

cept of "sexual activity with a child". Ukraine has not yet fulfilled its obligation to criminalize harassment as a separate type of conduct. The criminalization of female genital mutilation has occurred on a smaller scale than required by the Istanbul Convention. Ukraine's criminal law does not cover all variants of so-called sexual penetration without the consent of the person, criminalization of which is required by the Istanbul Convention. The criminalization of sexual assault which does not involve a sexual penetration seems incomplete due to the technical and legal defects of Article 153 of the Criminal Code. The new edition of Article 154 of the CC does not so much fulfill the requirements of the Istanbul Convention on the criminalization of coercion of acts of a sexual nature with a third party, as creates an incomprehensible "hybrid" of the provisions of the said Convention and the "old" edition of Article 154 of the CC.

Key words: crimes against sexual freedom and integrity, sexual abuse, domestic violence, harmonization of criminal law.

Постановка проблеми та іï актуальність. Нещодавно Верховною Радою України було прийнято закони України «Про внесення змін до Кримінального кодексу України щодо захисту дітей від сексуальних зловживань та сексуальної експлуатації» № 2334-VIII від 14.03.2018 року та «Про внесення змін до деяких законів України у зв'язку з метою реалізації положень Конвенції Ради Європи про запобігання насильству стосовно жінок і домашньому насильству та боротьбу з цими явищами» № 2227-VIII від 06.12.2017 року, які в сукупності докорінно змінили законодавчу характеристику злочинів проти статевої свободи та статевої недоторканості особи. Одним із чинників, які зумовили необхідність прийняття згаданих законів, була необхідність виконання Україною низки договірних міжнародно-правових зобов' язань щодо криміналізації діянь. Так, уже з назви Закону України № 2227-VIII від 06.12.2017 року випливає, що його метою $є$ приведення кримінального законодавства України у відповідність із вимогами Конвенції Ради Європи про запобігання насильству стосовно жінок і домашньому насильству та боротьбу з цими явищами від 2011 року (так звана Стамбульська конвенція). 3 тексту пояснювальної записки до Закону України № 2334-VIII від 14.03.2018 року своєю чергою випливає, що метою цього акту $\epsilon$, зокрема, приведення окремих положень кримінального законодавства України у відповідність із статтями 18(1)(a) та 18(2) Конвенції Ради Європи про захист дітей від сексуальної експлуатації та сексуального насильства від 2007 року (так звана Лансаротська конвенція).

Аналіз останніх досліджень i публікацій. Новели кримінального законодавства, які привнесли з собою закони України № 2227-VIII від 06.12.2017 року 
та № 2334-VIII від 14.03.2018 року, вже були предметом уваги українських науковців [1; 2; 3; 4], однак видається, що питання про те, наскільки прийняття цих законів забезпечує досягнення задекларованої законодавцем мети виконання договірних міжнародно-правових зобов'язань, поки не було предметом акцентованої уваги у наукових публікаціях.

Метою статті $\epsilon$ аналіз нових положень кримінального законодавства України, що встановлюють відповідальність за злочини проти статевої свободи та статевої недоторканості особи, на перемет їх відповідності положенням Стамбульської та Лансаротської конвенцій, а також формулювання пропозицій щодо їх вдосконалення у разі, якщо така відповідність буде відсутня.

Виклад основного матеріалу. 3 набранням чинності Законом України № 2334-VIII від 14.03.2018 року було викладено в новій редакції ч. 1 ст. 155 КК, яка нині встановлює відповідальність за «природні або неприродні статеві зносини з особою, яка не досягла шістнадцятирічного віку, вчинені повнолітньою особою». Це законодавче рішення, яке, однак, $\epsilon$ вкрай спірним з огляду на задекларовану в пояснювальній записці мету досягнути відповідності українського кримінального закону певним положенням Лансаротської конвенції. Зокрема, складається враження, що автори пояснювальної записки до Закону України № 2334-VIII від 14.03.2018 року невірно розуміли справжнє правове значення так званого віку, до досягнення якого забороняється займатися діяльністю сексуального характеру з дитиною (age below which it is prohibited to engage in sexual activities with a child), про який ідеться в статтях 18(1)(a) та 18(2) Лансаротської конвенції.

Так, у тексті пояснювальної записки наголошується, що через зміни до ч. 1 ст. 155 КК: «[В]становлюється мінімальний вік статевого повноліття, що відповідає рекомендаціям Комітету ООН з прав дитини, а також не виникає потреби в обов'язковому проведенні судово-медичної експертизи для встановлення статевої зрілості потерпілої особи, що суттєво полегшує процес кваліфікації та доказування цього злочину. Крім того, використання запропонованого у законопроекті вікового критерію та відмова від вживання терміна «статева зрілість» різко знизить ймовірність об'єктивного ставлення у провину, оскільки суб'єктивна сторона цього складу злочину вимагає від винного усвідомлення, що потерпіла особа не досягла статевої зрілості. Водночас фізіологічний (статевий) розвиток $\epsilon$ індивідуальним і встановлення факту недосягнення потерпілою особою статевої зрілості не рідко вимагає спеціальних знань, а в окремих випадках $€$ неможливим без проведення відповідної експертизи».

Подібні судження, на жаль, абсолютно ігнорують той факт, що конвенційне поняття «вік, до досягнення якого забороняється займатися діяльністю сексуального характеру з дитиною» істотно відрізняється від поняття «статева зрілість», яке використовувалося в чинній раніше редакції статті 155 КК. Наприклад, у Дослідженні комітету держав - учасниць Лансаротської конвенції щодо імплементації їі статті 23 (2015) неодноразово вказується на те, що вік, до досягнення якого забороняється займатися діяльністю сексуального характеру з дитиною, $є$ нічим інакшим, як так званим віком згоди (age of consent), тобто віком, з досягненням якого пов'язується здатність особи висловлювати згоду на участь у сексуальній діяльності.
Таким чином, стаття 18(1)(а) Лансаротської конвенції вимагає криміналізувати заняття діяльністю сексуального характеру з дитиною, яка не досягла передбаченого законодавством віку для заняття діяльністю сексуального характеру, оскільки ця діяльність вважається такою, що здійснюється без згоди дитини, а не з міркувань того, що вона фізіологічно нездатна вести нормальне статеве життя, як це передбачала чинна раніше ст. $155 \mathrm{KK}$.

Якщо законодавець шукав в українському кримінальному праві концепт чи поняття, яке було б подібне до віку, до досягнення якого забороняється займатися діяльністю сексуального характеру з дитиною, що згадується в положеннях Лансаротської конвенції, то він мав би звернути увагу не на концепт статевої зрілості, що згадувався в ст. 155 КК, а на концепт безпорадного стану, який згадувався в ст.ст. 152 та 153 КК. Адже згідно з усталеними підходами судової практики України одним із показників безпорадного стану міг бути малолітній вік потерпілого (абз. 1 п. 5 постанова Пленуму Верховного Суду України від 30.05.2008 року № 5), зокрема, якщо такий вік не давав малолітній особі можливості «усвідомлювати характер та значення вчинюваних з нею дій».

Таким чином, впровадження у правову систему Україні концепту «віку згоди» мало б відбуватися перш за все шляхом внесення змін до ст.ст. 152 та $153 \mathrm{KK}$, а не до ст. 155 КК. Зрештою, законодавець створив серйозну невизначеність з приводу того, яким же насправді $\epsilon$ вік згоди за кримінальним правом України, оскільки на додачу до нової редакції ч. 1 ст. 155 КК він передбачив у нових редакціях частин четвертих ст.ст. 152 та 153 КК те, що відповідальність за дії сексуального характеру стосовно дитини віком до 14 років настає незалежно від добровільної згоди потерпілого.

Формулювання «природні або неприродні статеві зносини», яке міститься у тексті чинної редакції ч. 1 ст. 155 КК, також складно назвати вдалим з огляду на задеклароване законодавцем прагнення виконати вимоги Лансаротської конвенції. У статтях 18(1)(а) та 18(2) цієї Конвенції використовується не поняття «природні або неприродні статеві зносини [3 дитиною]», а поняття «діяльність сексуального характеру з дитиною». Якщо перше із вказаних понять семантично передбачає безпосередній фізичний контакт між дорослим та дитиною, то друге має значно ширший зміст. Зокрема, з Думки Комітету держав - учасниць Лансаротської конвенції щодо їі статті 23 (2015) та Пояснювального коментарю до неї випливає, що «діяльність сексуального характеру» має тлумачитись у тексті цього міжнародного договору дуже широко та може, наприклад, полягати й у так званих «онлайн зустрічах» дорослого та дитини. Чинна ж редакція ч. 1 ст. 155 КК особливостей конвенційної термінології геть не враховує.

Хоча Закон України № 2227-VIII від 06.12.2017 року мав за мету забезпечити реалізацію положень Стамбульської конвенції, в аспекті криміналізації діянь він робить це неповною мірою. Зокрема, він не забезпечив встановлення кримінальної відповідальності за переслідування, криміналізації якого вимагає стаття 34 Стамбульської конвенції: «Сторони вживають необхідних законодавчих або інших заходів для забезпечення того, щоб умисну поведінку, яка полягає в повторному здійсненні загрозливої поведінки, спрямованої на іншу особу, що змушує його чи їі боятися за свою безпеку, 
було криміналізовано». Зауважимо, що характеристики типу поведінки, про який ідеться в статті 34 Стамбульської конвенції, не давали підстав законодавцю вважати, що відповідальність за подібну поведінку вже встановлена за кримінальним законодавством України. щонайбільше, можна вести мову про криміналізацію лише окремих їі проявів.

Стаття 38 Стамбульської конвенції вимагає від держав-учасниць криміналізації каліцтва жіночих геніталій: «Сторони вживають необхідних законодавчих або інших заходів для забезпечення того, щоб було криміналізовано такі форми умисної поведінки: а) видалення, інфібуляція або здійснення будь-якого іншого каліцтва загалом або частково великих статевих губ, малих статевих губ або клітора; b) примушування жінки до того, щоб вона зазнала актів, перелічених у підпункті «а», або схилення іï до цього; с) підбурювання, примушування дівчини до того, щоб вона зазнала актів, перелічених у підпункті «а», або схилення їі до цього».

$\mathrm{Ha}$ перший погляд може скластись враження, що це зобов'язання Закон України № 2227-VIII від 06.12.2017 року виконує «із запасом», оскільки згідно з передбаченими ним змінами до ч. 1 ст. 121 КК різновидом тяжкого тілесного ушкодження визнається каліцтво статевих органів (очевидно, і жіночих, і чоловічих). На жаль, такий підхід не враховує традиційного у правовій системі України тлумачення зазначеного положення кримінального закону, а також природи зобов'язання, передбаченого статтею 38 Стамбульської конвенції:

По-перше, попри відсутність у ч. 1 ст. 121 КК прямої вказівки, традиційне судове та доктринальне тлумачення цього положення враховує згоду потерпілого (особи) [5, с. 423]. Таким чином, згода потерпілого може бути обставиною, яка виключає кримінальну відповідальність за заподіяння умисного тяжкого тілесного ушкодження. Отже, доповнення ч. 1 ст. 121 КК згадкою про каліцтво статевих органів матиме наслідком поширення подібного правового режиму й на цей тип поведінки. Відповідно, згода потерпілого (особи) виключатиме кримінальну відповідальність за каліцтво статевих органів. Інакше кажучи, ушкодження статевих органів, завдані потерпілому з його згоди, не будуть в принципі вважатись каліцтвом статевих органів у розумінні пропонованої редакції ч. 1 ст. 121 КК. 3 іншого боку, звертає на себе увагу те, що в тексті Стамбульської конвенції положення про каліцтво жіночих геніталій відмежовано від положень про фізичне та психологічне насильство (статті 33, 35 Конвенції). У поєднанні з буквальною інтерпретацією статті 38 договору такий статус-кво означає, що останнє положення вимагає від держав-учасниць абсолютної заборони каліцтва жіночих геніталій, незалежно від згоди потерпілої особи. Підтвердженням необхідності саме такого тлумачення статті 38 Стамбульської конвенції виглядає законодавча практика європейських держав, які $\epsilon$ учасницями зазначеного договору. Наприклад, ст. 409 КК Бельгії, ст. 149 КК Іспанії, ст. 233А КК Кіпру встановлюють кримінальну відповідальність за каліцтво жіночих геніталій незалежно від згоди потерпілого.

Отже, можна припустити, що прийняття Закону України № 2227-VIII від 06.12.2017 року не забезпечило повної відповідності кримінального законодавства України вимогам Стамбульської конвенції в частині криміналізації каліцтва жіночих геніталій. Залишаються не кримінально караними такі діяння, як: 1) каліцтво жіночих геніталій за наявності згоди потерпілого (особи) (стаття 38(а) Конвенції); 2) підбурювання та примушування потерпілої до того, щоб вона зазнала таких дій (статті 38(b) та 38 (c) Конвенції).

Зміни до статей 152-154 КК, передбачені Законом України № 2227-VIII від 06.12.2017 року, також мали за мету привести згадані положення у відповідність зі статтею 36(1) Стамбульської конвенції, яка вимагає криміналізації сексуального насильства: «1. Сторони вживають необхідних законодавчих або інших заходів для забезпечення того, щоб було криміналізовано такі форми умисної поведінки: а) здійснення, без згоди, вагінального, анального або орального проникнення сексуального характеру в тіло іншої особи з використанням будь-якої частини тіла або предмета; b) здійснення, без згоди, інших актів сексуального характеру з особою; с) примушування іншої особи до здійснення, без згоди, актів сексуального характеру з третьою особою».

Загалом можна погодитися із тим, що положення кримінального закону, які на момент 2017 року встановлювали відповідальність за статеві злочини, істотно не відповідали зобов'язанням України за Стамбульською конвенцією. Найбільш яскравий приклад: чинні раніше редакції ст.ст. 152 та 153 КК охоплювали лише окремі прояви сексуальних дій, вчинених щодо потерпілої особи без їі добровільної згоди, тоді як міжнародне право вимагає криміналізації усіх випадків, коли статеві зносини мали місце без згоди потерпілого (наприклад, потерпіла особа вступила у статеві зносини в обстановці, яка унеможливлювала ії добровільну згоду).

Однак, на жаль, Закон України № 2227-VIII від 06.12.2017 року наблизив кримінальне законодавство України до вимог статті 36 Стамбульської конвенції доволі фрагментарно.

По-перше, стаття 36(1)(а) Конвенції вказує, що так зване статеве проникнення може бути вчинене винним за допомогою будь-якої частини тіла або предмета, але в новій редакції ч. 1 ст. 152 КК натомість вжите формулювання «з використанням геніталій або будьякого іншого предмета», яке може розумітись неоднозначно: випадки статевого проникнення з використанням інших частин тіла, аніж геніталії, можуть як охоплюватись поняттям «будь-який інший предмет», так і не охоплюватись ним. В останньому випадку такі діяння за наявності відповідних обставин можуть підпадати під нову редакцію ч. 1 ст. 153 КК, однак остання сама по собі відзначається серйозною неузгодженістю зі статтею 36(1)(b) Конвенції (див. про це нижче).

По-друге, так само не відповідає тексту статті 36(1)(a) Конвенції формулювання «дії сексуального характеру, пов'язані з... проникненням...» в тексті чинної редакції ч. 1 ст. 152 КК. 3 його буквального тлумачення випливає, що самого факту статевого проникнення за відсутності добровільної згоди потерпілого не буде достатньо для кримінальної відповідальності винного.

По-третє, істотно не відповідає статті 36(1)(b) Конвенції нова редакція ч. 1 ст. 153 КК. Зокрема, в ній відповідальність особи пов'язується з вчиненням будьяких насильницьких дій сексуального характеру, не пов'язаних із проникненням в тіло іншої особи, без добровільної згоди потерпілої особи. Стаття 36(1)(b) Стамбульської конвенції своєю чергою говорить про «здійснення, без згоди, інших актів сексуального харак- 
теру з особою». Тобто такі акти, по-перше, не обов'язково можуть мати насильницький характер, по-друге, вони можуть навіть не передбачати фізичного контакту 3 потерпілим. Відзначимо, що в тексті Пояснювальної доповіді до Стамбульської конвенції максимально обтічно вказується, що під актом сексуального характеру слід розуміти будь-який акт, що має сексуальний підтекст. Понад те, навіть поняття «задоволення статевої пристрасті неприродним способом», що передбачалося чинною раніше редакцією статті $153 \mathrm{KK}$, не зводилося до дій, що передбачають фізичний контакт з потерпілим (див. абз. 1 п. 2 постанови Пленуму Верховного Суду України № 5 від 30.05.2008 року). Отже, в підсумку нова редакції ч. 1 ст. 153 КК встановлює відповідальність за істотно вужче коло діянь, аніж того вимагає стаття 36(1)(b) Конвенції.

По-четверте, стаття 36(1)(c) Конвенції закріплює зобов'язання криміналізувати примушування до здійснення, без згоди, актів сексуального характеру з третьою особою. На думку авторів цієї статті, станом на момент прийняття Закону України № 2227-VIII від 06.12.2017 року такий тип поведінки не можна було вважати кримінально караним згідно з чинним на той момент законодавством. Буквальне тлумачення чинних раніше редакцій статей 152 та 153 КК начебто не виключало того, що фізичне або психічне насильство може бути «розірване» у часі від статевих зносин чи задоволення статевої пристрасті неприродним способом. Це свою чергою створювало підстави для кваліфікації щонайменше окремих діянь, які охоплюються статтею 36(1)(c) Конвенції, як співвиконавства у злочинах, передбачених чинними раніше редакціями ст.ст. 152 та 153 КК. Однак із загального контексту п.п. 3, 4 постанови Пленуму Верховного Суду України № 5 від 30.05.2008 року випливає, що під час вчинення злочинів, передбачених чинними раніше редакціями ст.ст. 152 та 153 КК, насильство все ж повинно було мати негайний характер. Таким чином, виконання зобов'язання щодо криміналізації примушування до здійснення, без згоди, актів сексуального характеру з третьою особою і справді потребувало законодавчих змін. Однак, на жаль, законодавець обрав загалом невдалий варіант розв'язання цієї проблеми та обмежився доволі «консервативною» модифікацією чинної раніше редакції статті $154 \mathrm{KK}$.

Зокрема, нова редакція ч. 1 ст. 154 КК доволі очевидно відрізняється від статті 36(1)(с) Стамбульської конвенції, встановлюючи відповідальність за «примушування особи без їі добровільної згоди до здійснення акту сексуального характеру з іншою особою». У такій формулі вказівка на відсутність добровільної згоди особи займає відверто не «своє» місце та тим самим спотворює логіку статті 36(1)(c) Конвенції. Остання пов'язує відсутність добровільної згоди потерпілого зі здійсненням актів сексуального характеру, але не із самим примушуванням. Це означає, що умислом винного має обов' язково охоплюватись усвідомлення того, що для потерпілого не $\epsilon$ прийнятною участь в актах сексуального характеру з третьою особою (відсутність згоди потерпілого на це). 3 іншого боку, в пропонованій ч. 1 ст. 154 КК акцент зміщено у бік примушування, адже саме з ним пов'язується відсутність добровільної згоди потерпілого. Причому така вказівка взагалі видається самоочевидною. Примушування потерпілої особи до певних дій може мати місце лише тоді, коли той, до кого застосовують примус, не дає на це добровільної згоди. Відповідно, наявність добровільної згоди потерпілого виключає оцінку дій винного як примусу, примушування. Однак найгірше, що через зміщення акцентів ч. 1 ст. 154 КК в чинній редакції передбачає, що умислом винного має охоплюватись усвідомлення неприйнятності для потерпілого тих дій (насильства, погроз тощо), які спонукають останнього до здійснення актів сексуального характеру з третьою особою. При цьому не мають правового значення такі обставини, як: 1) прийнятність чи неприйнятність для потерпілого самих актів сексуального характеру з третьою особою (наявність його добровільної згоди на здійснення таких актів); 2) усвідомлення чи неусвідомлення попередніх фактів винним. У підсумку чинна редакція ч. 1 ст. 154 КК буде застосовуватися, зокрема, й тоді, коли: 1) винний примушує потерпілу особу до актів сексуального характеру з третьою особою; 2) такі акти насправді $\epsilon$ прийнятними для потерпілого; 3) винний не знає про вказану обставину. Подібне законодавче рішення справляє враження надмірної та невиправданої криміналізації порівняно з вимогами статті 36(1)(с) Стамбульської конвенції.

Крім того, ще більше спотворює суть конвенційного положення ч. 2 ст. 154 КК, в якій посилення кримінальної відповідальності пов'язується з «[примушуванням] до здійснення акту сексуального характеру з особою, від якої потерпіла особа матеріально або службово залежна». Якщо третя особа лише користується результатами примушування потерпілого з боку винного, чому в такому разі залежність потерпілого від третьої особи повинна мати правове значення, адже в контексті конкретних дій сексуального характеру така залежність реально невикористовується длявпливунапотерпілого?!

Таким чином, чинна редакція статті 154 КК не так імплементуєвкримінальнезаконодавствостаттю36(1)(с) Стамбульської конвенції, як створює малозрозумілий «гібрид» цього конвенційного положення та «старої» редакції згаданої статті КК.

Висновки. Попри те, що задекларованими цілями прийняття законів України № 2227-VIII від 06.12.2017 року та № 2334-VIII від 14.03.2018 року $\epsilon$ наближення кримінального законодавства України до вимог Стамбульської конвенції та окремих вимог Лансаротської конвенції, в реальності, на жаль, згадані цілі значною мірою не були досягнуті:

1) впровадження у кримінальне законодавство концепту «вік, до досягнення якого забороняється займатися діяльністю сексуального характеру з дитиною» відбулося у вельми непослідовний та безсистемний спосіб;

2) формулювання «природні або неприродні статеві зносини» в чинній редакції ч. 1 ст. 155 КК охоплює далеко не всі ситуації, які позначає конвенційне поняття «діяльність сексуального характеру з дитиною»;

3) Україною й досі не виконане зобов'язання щодо криміналізації переслідування як окремого типу поведінки;

4) криміналізація каліцтва жіночих геніталій відбулася в меншому обсязі, аніж того вимагає Стамбульська конвенція;

5) кримінальне законодавство України охоплює не всі варіанти так званого статевого проникнення без 
згоди особи, криміналізації якого вимагає Стамбульська конвенція;

6) криміналізація сексуального насильства, що не характеризується статевим проникненням, через техніко-юридичні вади статті 153 КК справляє враження неповної;

7) нова редакція статті $154 \mathrm{KK}$ не так забезпечує виконання вимог Стамбульської конвенції щодо криміналізації примушування до актів сексуального характеру 3 третьою особою, як створює малозрозумілий «гібрид» положення згаданої Конвенції та «старої» редакції статті $154 \mathrm{KK.}$

Перераховані вище вади, на жаль, означають лише одне. У подальшому положення розділу IV Особливої частини КК потребуватимуть додаткових змін з метою досягти відповідності українського кримінального закону з вимогами міжнародних конвенцій.

\section{Література}

1. Дудоров 0.О. Злочини проти статевої свободи та статевої недоторканості особи (основні положення кримінально-правової характеристики): практ. порадник ; МВС України, Луган. держ. ун-т внутр. справ ім. Е.О. Дідоренка. Сєвєродонецьк : РВВ ЛДУВС ім. Е.О. Дідоренка, 2018. 92 с.

2. Дудоров О.О., Хавронюк М.І. Відповідальність за домашнє насильство і насильство за ознакою статі (нау- ково-практичний коментар новел Кримінального кодексу України) / за ред. М. І. Хавронюка. Київ : Ваіте, 2019. 288 с. 3. Мовчан Р.О., Шушкова А.П. Сексуальна революція по-українськи та інші новели Закону № 2227-VIII: крок до Європи чи в нікуди? Науковий вісник Ужгородського національного університету. Серія Право. 2018. Вип. 51. Т. 2. С. 75-79.

4. Харитонова О.В. Ключові засади ґендерної політики в кримінальному праві України та основні напрями реформ щодо протидії насильству стосовно жінок та домашньому насильству: науково-практичний посібник. Харків : Права людини, 2018. 344 с.

5. Зенова М.В. Поняття, ознаки й види згоди (прохання) потерпілого. Актуальні проблеми держави і права. 2014. Вип. 71. С. 419-426.

Давидович І. І., кандидат юридичних наук, доцент кафедри кримінального права та кримінології Київського начіонального університету імені Тараса Шевченка

Задоя К. П., кандидат юридичних наук, дочент кафедри кримінального права та кримінології Київського національного університету імені Тараса Шевченка 